\title{
A systematic review of dividend policy in relation to stock price volatility
}

\section{Sheena Bhatta ${ }^{1}$ and Bal Ram Duwal, $\mathrm{PhD}^{2}$}

${ }^{1}$ Central Department of Management-

Tribhuvan Univesity, Nepal,

sheenabhatt010@gmail.com

${ }^{2} \mathrm{PhD}$, Assistant Professor, Central

Department of Management, Tribhuvan

University, Nepal, Corresponding author, email-, balramduwal@gmail.com

Received on: Dec 3, 2021

Revised on : 12th Dec 2021

Accepted date: Dec 13, 2021

\section{Cite this paper}

Bhatta, S. and Duwal, B. (2021). A

Systematic Review of Dividend Policy

in Relation to Stock Price. International

Research Journal of Management

Science, vol.6(1), pp. 92-104

\begin{abstract}
When it comes to determining a dividend policy that would maximize shareholder value, focusing merely on how much of the firm's profit is necessary for dividend distribution and reinvestment is insufficient. It is critical to analyze the impact of their dividend choice on the stock price.The purpose of this study is to scrutinize the impact of dividend policy on stock price volatility. The report investigated the relationship between the dividend policy and stock price volatility taking 8 articles between 2010 to 2020 . Likewise, following a systematic literature review method, the study critically. analyzed the selected articles based on their strengths and weaknesses. The findings suggest that, in most of the cases demonstrated by authors, dividend policy has a significant negative relationship with the stock price volatility. The stock's price volatility often decreases after the declaration of dividend payout ratio and dividend yield. Based on the results of this study, it can be implied that, managers of manufacturing companies and banks, those listed in the stock exchange, may be able to reduce the price volatility of their stock by increasing dividend payout and dividend yield. Since the study is limited to 4 databases, further studies could include some more articles from top-rated databases that signify dividend policy in diverse sectors to derive even more accurate results.
\end{abstract}

Keywords: Dividend policy, Stock price volatility, dividend yield, dividend announcement, dividend payout 


\section{Introduction}

A dividend is a payment made by a firm of a portion of its profit to the individuals who own stocks in the company, known as shareholders. Dividends significantly improve stock investment earnings, offer consistent income, and enhance shareholder morale.Companies offer several types of dividends among which include the most popular being cash dividend and stock dividend. Cash dividends are paid out in cash and placed in shareholders' bank accounts. While a stock dividend is the issuance of extra shares to shareholders without any consideration (Huang et al., 2009). To issuethese dividends, the company follows different dividend policies like regular, stable, irregular and no dividend policy. Every year, the corporation distributes dividends to its stockholders underneath the regular dividend policy. The proportion of profits paid out as dividends is predetermined under the stable dividend policy. The company is not required to pay its shareholders following irregular dividend policy, and the board of directors can determine what to do with the proceeds. The company does not pay out dividends to shareholders under the no dividend policy. The method of dividend policy can impact the stock price volatility. The systemic risk that ordinary stockholders have widely experienced is regarded as stock price volatility. It is a pace over which the value of a security is increased or drops for a particular set of returns (Zainudin et al., 2018).

To lessen the issue of agency cost, the managers must make dividend decisions on a frequent basis. This includes deciding whether or not to pay revenues to shareholders. They must choose between investing in profitable businesses and paying out the free cash to shareholders (Shah \& Noreen, 2016). According to the available literature, the question still remains if paying out revenues creates value for shareholders and if it has an impact on the stock prices. Considering the significance of this corporate policy, scholars continue to be interested in the impact of dividend decisions on stock prices, especially in the developing countries. The relation of dividend policy with stock price volatility is still unclear, with various academics debating whether dividend policy has an impact on stock price volatility (Hamid et al., 2017). The question has been raised about whether corporate dividend policies have any bearing on stock price movement. As a result, this research evaluates past research to see if dividend policy affects stock price volatility. The research is expected to provide new perspectives for the policymakers to improve the efficiency of the stock exchange market, and it is also intended to provide an insight into the stock price response as an outcome of dividend announcements, that the investors could use to make better rational and efficient investment decisions.

\section{Review of Literature}

A literature review is a summary of formerly published works on a certain topic. It can be referred entire scholarly document or a piece of a scholarly work, such as a book or an article. The literature review for this specific study on the topic "A systematic review of dividend policy in relation to stock price volatility" comprises of the previously published scholarly articles. This section comprises of the discussion of underlying theories associated to the dividend policy, literature review matrix of the 8 selected articles and critical analysis based on the review of those articles.

A theory is a set of concepts and propositional links that together give a logical, systematic, and cohesive 
explanation of a phenomena of interest, subject to certain hypotheses and boundary conditions. Some of the related theories discussed in this section comprises of dividend irrelevance theory, bird-in-the-hand theory, signaling theory, agency cost theory and clientele effect theory.

\subsection{Review of Theories}

\section{a. Dividend Irrelevance Theory}

Miller and Modigliani (M\&M) introduced the Dividend Irrelevance Theory in 1961. It hypothesizes that in an ideal society where there are no corporate and personal taxes, no transaction and flotation costs, and no single person that can influence the price of a security by his or her trading, everyone has same expectations about a corporation's future investment and profit. Alongside, the value of a firm and consequently its share prices are not impacted by dividend distributions (Priya \&Mohanasundari, 2016). It implies that dividend policy does not have an impact on stock price, and therefore the company's value would not be harmed in a perfect capital market (Miller \& Modigliani, 1961).

\section{b. The Bird-in-the-hand theory}

Dividends, according to the bird in the hand school of philosophy, are beneficial and will boost shareholder wealth from their impact on stock price. The primary advocate of the bird-in-the-hand theory (Gordon, 1962.) discovered that stockholders value a dollar in dividends received more than a dollar in retained earnings. As a result, dividend policy influences the value of stocks. This hypothesis claims, especially, that the investors are unconcerned with the difference between payouts at present times and future capital gains. Instead of a more unpredictable financial benefit tomorrow, they chose a more assured dividend presently (Priya \&Mohanasundari, 2016). Investors discount the predicted capital gain yield at a larger percentage than the dividend yield, according to the hypothesis.

\section{c. Signaling theory}

The signaling hypothesis illustrates how increasing dividend payouts send out positive signals towards the markets about a corporation's future earnings, resulting the upward share price movements and conversely. It implies that a corporation's announcement of increased dividend payouts portends better future possibilities (Fairchild et al., 2014). The asymmetric information issue, which gives relevance to the signaling theory, is one of the defects that is crucial to the growth of ideas connected to payout. It is also known as the dividend hypothesis' information content. According to this theory, dividend announcements are seen to contain information content, with management using cash dividend announcements to convey modifications in the expectations about the corporation's future prospects when markets are not perfect (Fairchild et al., 2014). The information content of a dividend announcement might induce shareholders to respond to the announcement and, as a result, affect the price of the stock price.

\section{d. Agency cost theory}

Dividend payments reduce agency costs among shareholders and managers, according to agency cost theory. (Patra et al., 2012). The manager's dedication to enhancing the shareholder's investment fund without the need of investing the funds in hazardous and unproductive ventures is demonstrated by dividend distribution. The dividend mechanism, according to agency theory, offers incentives for managers to lower costs associated with the principal-agent relationship, and one approach to decrease 
agency costs is to raise payouts (Alzomaia\&Khadhiri, 2013).

\section{e. Clientele effect theory}

The clientele effect is a hypothesis that claims that different approaches attract different sorts of investors, and also that disparities in policies would result in a change in investor demand for the company's shares, affecting the share price. The hypothesis that variations in a company's dividend policy may result in some customers selling their stock and attracting new customers who might buy stock depending on dividend preferences (Farrukh et al., 2017). It refers to the presence of investor groups that are drawn to businesses with distinct policies. This idea proposes that when a variation in dividend, tax, or other policy changes investors' investment intentions, they might have a significant effect on the price of a securities. If a company's dividend policy varies and differs significantly from the investor's preferences, current clients may choose to sell their stock.

\subsection{Definition of Variables/Terms}

\subsubsection{Dependent variables}

a. Stock price volatility (SPV): Stock price volatility is applied to determine the risk of a common stock, with the higher the volatility, the higher the risk. The variability or divergence of an asset's returns from its mean is characterized as volatility (Zainudin et al., 2018). Volatility is calculated by evaluating at how much an asset or group of asset prices differs from the average price.

\subsubsection{Independent variables}

a. Dividend payout ratio (DPR): The dividend payout ratio is the proportion of the total amount of dividends given to shareholders to the company's earnings. It is the amount of earnings that is delivered to shareholders as dividends (Fitri et al., 2016).

b. Dividend announcement: A dividend announcement occurs when a company's board of directors declares an impending dividend payment, generally through a press release issued some few weeks before the dividend is paid.

c. Dividend policy: The term "dividend policy" pertains to a corporation's economic decisions on whether to distribute a cash dividend now or a greater dividend payment subsequently. The amount and frequency at which dividends are paid to shareholders are regulated by a company's dividend policy (Husain \&Sunardi, 2020). The percentage of profits given out as dividends is predetermined under the stable dividend policy.

d. Dividend Yield: Dividend yield is a financial statistic that compares the amount of cash dividends distributed to shareholders to the market value per share. The yearly dividend payments to shareholders represented as a percent of the stock's current price is known as dividend yield (Zainudin et al., 2018).

\subsection{Empirical Review}

Ali and Chowdhury (2010) researched about the effect of dividend on stock price in listed private commercial banks in DSE” in 2010 with an objective to determine if dividend announcements communicate any information to the market, resulting in a price reaction that may be used to change 
the dividend announcement content. The relation between the dividend announcements and stock price changes has been established; a standard event study methodology concluded that there is no concrete evidence that the stock price responds significantly to dividend announcements. However, this result contradicts with many other researches. Likewise, the authors have established theoretical framework, however, the study fails to state its findings in relation to dividend policy theories. Additionally, the authors have not mentioned any implication of their result and have not provided any suggestions for further researches. The limitations of the study are not acknowledged by the authors.

Okafor and Mgbame (2011) studied about the dividend policy and share price volatility in Nigeria taking 10 publicly quoted firms as their sample. The findings imply that dividend yield has a general negative impact on share price risk. Dividend payout ratio has negative influences in some years and positive influences on other at lower significant levels. One of the strengths of their study is that they have tried to explain with an attempt exploring how business dividend policies affect stock prices, including the clientele effect, the information or signaling effect, the bird-in-hand hypothesis, and the rate of return effect. The study is not just focused on the impact that dividend policy has on the stock price, but also covers several issues in dividend policy such as what are our investment opportunities, what business risk do we suffer, who are our stockholders, how is our liquidity position and is control an issue. The study assists the fact that dividend policy has relevance in determining share price. Analyzing the study, in the light of changing landscape of the emerging dividend policies and conflicts in the management, the findings from the study might not be relevant to the contemporary context.

Hussainey et al. (2011) researched about the dividend policy and share price volatility taking a sample of publicly quoted companies in the UK. The empirical results demonstrate that there is a strong negative association between a firm's payout ratio and the volatility of its stock price, as well as a negative relationship of dividend yield with stock price volatility. The study relates the findings back to a wide array of other research studies that concluded a negative relationship between dividend policies and stock price volatility, which is a strength of this part of the report.

Hashemijoo et al. (2012) studied about the impact of dividend policy on share price volatility in the Malaysian stock market taking a sample of 84 companies from 142 consumer product companies listed in main market of Bursa Malaysia. The article has taken a good amount of sample i.e. 84 companies, which contributes to more accurate results of the study. One of the strengths of the study is that they the authors have developed hypothesis and based their results accordingly. The authors have also emphasized on the criteria for the selection of their sample such as: the sampled firms had at least one cash dividend payment during 2004 to 2010 and did not have stock split during 2005 to 2010. The study does not limit its findings to the concrete objective of understanding the association between dividend policy and stock price, nevertheless, the study also discusses other control variables that impact the stock prices. The empirical findings of the study revealed a substantial negative association between share price volatility and the two primary measures of dividend policy, dividend yield and payout. The authors have discussed how their findings supported and contradicted the previous studies by researches. In a nutshell, the study has well covered every aspects of their research objectives and set out implication of their results for Malaysian stock market. 
Hunjra et al. (2014) studied about the impact of dividend policy on stock prices taking 63 companies listed at Karachi stock exchange, Pakistan. Such large sample certainly leads to a greater accuracy of results, which is a strength of the study. The authors have also covered the recommendation and practical implication based on their findings. Since the authors have taken samples from Pakistan, their results would be proved to be valid only in emerging nations like Pakistan. The study's findings revealed that dividend yield and dividend payout ratio had a substantial influence on stock price. Dividend yield has a strong negative influence on stock prices, but dividend payout ratio has a positive effect on stock prices. Despite getting a significant relationship between dividend policy and stock price volatility, the studyhas how the stock prices are uncontrollable, which most of the contemporary firms can relate to.

Zainudin et al. (2018) researched about dividend policy and stock price volatility of industrial products firms in Malaysia taking 166 industrial products public-listed firms. The findings of this study too can be proved to greatly accurate because of the presence of large sample. The strength of this study is that the authors have examined the relationship between dividend policy and stock price changes particularly during the post-crisis period. Overall, the results demonstrate a substantial negative association between a firm's dividend payout ratio and stock price volatility, as well as a strong negative relationship of dividend yield with stock price volatility. These results imply that dividend policy has a significant impact on stock price volatility in the industrial goods sector. The greater the dividend payout and dividend yield, the lesser the stock price volatility. The authors have also acknowledged the limitation to their study, recommendation to the policy makers and suggestion to include other macroeconomic factors that affect the stock prices in future researches.

Camilleri et al. (2019) analyzed the effect of dividend policy on share price volatility of Mediterranean banks' stocks. The authors found dividend yield to be more significant indicator than the dividend payout for price volatility, where dividend yield exhibited a positive relation with stock price volatility. Since the authors have taken samples from several countries, the findings from their study about dividend yield having a positive relation with stock price can be proved to be accurate to some extent to numerous countries, which is a strong part of the study. Contrary to the author's conclusions, it is impossible to deny that the dividend-volatility link is just a modest contributor to total stock price volatility.

Ahmad et al. (2018) researched the effect of dividend policy on stock price volatility: empirical evidence from Amman stock exchange taking 228 listed firms. The sample again can lead to greater result accuracy because of its high number. According to the conclusions, both the primary factors of dividend policy, dividend yield, and dividend payment have a negative significant association with stock price volatility. This suggests that the greater the dividend yield and dividend payout of the businesses, the lesser the stock price volatility, resulting in greater stock price stability. The authors have discussed about how their results support the theory, but have not demonstrated any evidence by relating to past studies. The authors have not discussed about the implication of their results and have not acknowledged any limitations to the study, which depicts weakness in their report. 


\section{Methodology}

The article explores the relationship that dividend policy has with stock price volatility. In order to access the relevant research work, the study employed systematic literature review, which reviews the papers from secondary source.The PRISMA flowchart template is used to show the whole method of studies inclusion and exclusion.

The information for the study is gathered by a comprehensive analysis of scholarly journal articles from 2010 to 2020 . In the initial step, the key search words like terms "dividend policy", "stock price volatility, "dividend payout," and "market price" were used to access the articles. Second, scholarly databases, specifically, Emerald, Semantic Scholar, African Journal Online and Social Science Research Network were used to extract the journal papers. Based on the relevant key words, 8 sample journal articles were selected for the review, which were screened from 18 total articles. The 7 articles from 2010 having the number of citations above 50 were selected for the study. One article with 22 number of citationswas taken for the review as a result of strong relevance with the title of this study and being a recently published article i.e. 2019. The remaining 10 articles that were cited for less than 50 times are excluded from the study. To achieve the highest degree of relevance, articles written and published in English, peer-reviewed and published in international journals were selected for this study.

\subsection{PRISMA Flowchart}

The steps for systematic literature review through PRISMA Flowchart is shown below:

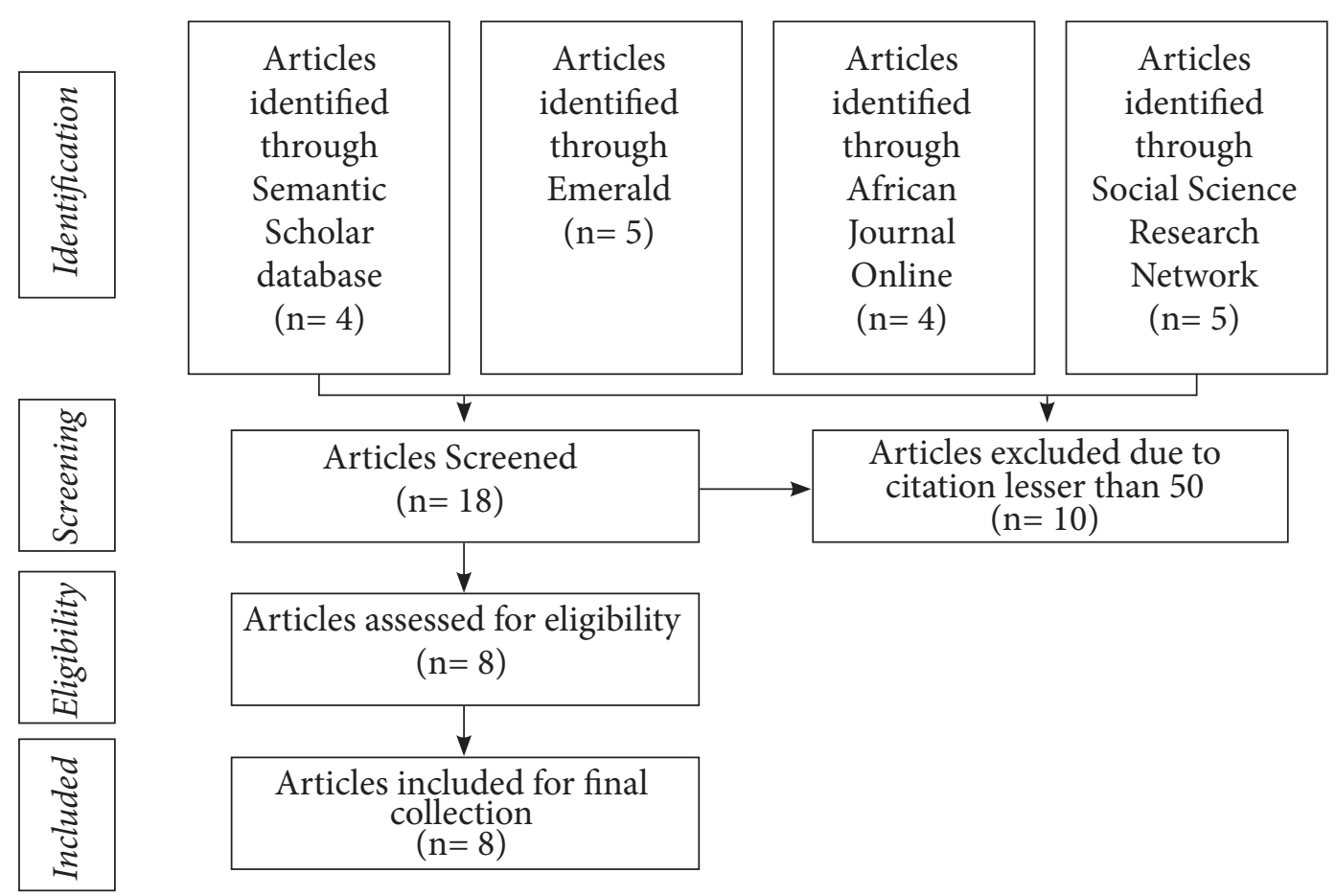

Figure 1: PRISMA Flowchart 


\section{Analysis and Discussion}

The final 8 selected papers are used for the analysis process. Debating views by several authors have been found regarding the impact of dividend policy on the stock price volatility. The findings are demonstrated in the following table:

\begin{tabular}{|c|c|c|c|c|c|}
\hline Authors & Title & Objective & Methodology & Variables used & Findings \\
\hline $\begin{array}{l}\text { Ali and } \\
\text { Chowdhur } \\
\text { y (2010) }\end{array}$ & $\begin{array}{l}\text { Effect of } \\
\text { Dividend on } \\
\text { Stock Price in } \\
\text { Emerging } \\
\text { Stock Market: } \\
\text { A Study on the } \\
\text { Listed Private } \\
\text { Commercial } \\
\text { Banks in DSE }\end{array}$ & $\begin{array}{l}\text { To identify } \\
\text { whetherdivide } \\
\text { nd } \\
\text { announcement } \\
\text { conveys any } \\
\text { information to } \\
\text { the market } \\
\text { that results a } \\
\text { price reaction } \\
\text { for adjusting } \\
\text { the dividend } \\
\text { announcement } \\
\text { information. }\end{array}$ & $\begin{array}{l}\text { Pooled t-test } \\
\text { at } 95 \% \\
\text { confidence } \\
\text { level, } \\
\text { correlation } \\
\text { analysis }\end{array}$ & $\begin{array}{l}\text { Stock price, } \\
\text { Dividend } \\
\text { announcement }\end{array}$ & $\begin{array}{l}\text { Dividend } \\
\text { announcement does } \\
\text { not convey any } \\
\text { information due to } \\
\text { strong contribution } \\
\text { of the insider } \\
\text { trading as well as } \\
\text { some other } \\
\text { influencing factors } \\
\text { in the capital } \\
\text { market }\end{array}$ \\
\hline $\begin{array}{l}\text { Okafor } \\
\text { and } \\
\text { Mgbame } \\
(2011)\end{array}$ & $\begin{array}{l}\text { Dividend } \\
\text { Policy and } \\
\text { Share Price } \\
\text { Volatility in } \\
\text { Nigeria }\end{array}$ & $\begin{array}{l}\text { To examine } \\
\text { the } \\
\text { relationship } \\
\text { between } \\
\text { dividend } \\
\text { policy and } \\
\text { share price } \\
\text { changes in the } \\
\text { Nigerian stock } \\
\text { market. }\end{array}$ & $\begin{array}{l}\text { Multiple } \\
\text { regression } \\
\text { analysis }\end{array}$ & $\begin{array}{l}\text { Price Volatility, } \\
\text { Divided Yield, } \\
\text { Payout } \\
\text { Ratio, Asset } \\
\text { Growth and } \\
\text { Earnings } \\
\text { Volatility }\end{array}$ & $\begin{array}{l}\text { Dividend yield } \\
\text { showed a general } \\
\text { negative impact on } \\
\text { share price risk. } \\
\text { Dividend payout } \\
\text { ratio showed } \\
\text { negative influences } \\
\text { in some years and } \\
\text { positive influences } \\
\text { on other at lower } \\
\text { significant levels. }\end{array}$ \\
\hline $\begin{array}{l}\text { Hashemijo } \\
\text { o et al. } \\
\text { (2012) }\end{array}$ & $\begin{array}{l}\text { The Impact of } \\
\text { Dividend } \\
\text { Policy on } \\
\text { Share Price } \\
\text { Volatility in } \\
\text { the Malaysian } \\
\text { Stock Market }\end{array}$ & $\begin{array}{l}\text { To examine } \\
\text { the } \\
\text { relationship } \\
\text { between } \\
\text { dividend } \\
\text { policy and } \\
\text { share price } \\
\text { volatility with } \\
\text { a focus on } \\
\text { consumer } \\
\text { product } \\
\text { companies } \\
\text { listed in } \\
\text { Malaysian } \\
\text { stock market. }\end{array}$ & $\begin{array}{l}\text { Regression } \\
\text { model }\end{array}$ & $\begin{array}{l}\text { Share price } \\
\text { volatility, } \\
\text { Dividend yield } \\
\text { and payout }\end{array}$ & $\begin{array}{l}\text { There is significant } \\
\text { negative } \\
\text { relationship } \\
\text { between share price } \\
\text { volatility with } \\
\text { dividend yield and } \\
\text { dividend payout. }\end{array}$ \\
\hline $\begin{array}{l}\text { Hunjra et } \\
\text { al. (2014) }\end{array}$ & $\begin{array}{l}\text { Impact of } \\
\text { Dividend } \\
\text { Policy, Earning } \\
\text { Per Share, } \\
\text { Return on } \\
\text { Equity, Profit } \\
\text { after Tax on } \\
\text { Stock Prices }\end{array}$ & $\begin{array}{l}\text { To examine } \\
\text { the effect of } \\
\text { dividend yield, } \\
\text { dividend } \\
\text { payout ratio, } \\
\text { return on } \\
\text { equity,earning } \\
\text { per share and } \\
\text { profit after tax } \\
\text { on stock prices } \\
\text { in Pakistan. }\end{array}$ & $\begin{array}{l}\text { Ordinary least } \\
\text { square } \\
\text { regression } \\
\text { model }\end{array}$ & $\begin{array}{l}\text { Stock prices, } \\
\text { Dividend yield, } \\
\text { dividend } \\
\text { payout ratio, } \\
\text { return on } \\
\text { equity, earning } \\
\text { per share and } \\
\text { profit after tax }\end{array}$ & $\begin{array}{l}\text { Dividend yield is } \\
\text { negatively related } \\
\text { with stock price and } \\
\text { dividend payout } \\
\text { ratio is positively } \\
\text { related with stock } \\
\text { price which means } \\
\text { that these results } \\
\text { are against } \\
\text { dividend } \\
\text { irrelevance theory. }\end{array}$ \\
\hline
\end{tabular}




\begin{tabular}{|c|c|c|c|c|c|}
\hline $\begin{array}{l}\text { Hussainey } \\
\text { et al. } \\
\text { (2011) }\end{array}$ & $\begin{array}{l}\text { Dividend } \\
\text { policy and } \\
\text { share price } \\
\text { volatility: UK } \\
\text { evidence }\end{array}$ & $\begin{array}{l}\text { To examine } \\
\text { the relation } \\
\text { between } \\
\text { dividend } \\
\text { policy and } \\
\text { share price } \\
\text { changes in the } \\
\text { UK stock } \\
\text { market. }\end{array}$ & $\begin{array}{l}\text { Multiple } \\
\text { regression } \\
\text { analyses }\end{array}$ & $\begin{array}{l}\text { Share price } \\
\text { changes, } \\
\text { Dividend yield } \\
\text { and dividend } \\
\text { payout ratio. }\end{array}$ & $\begin{array}{l}\text { A positive relation } \\
\text { is found between } \\
\text { dividend yield and } \\
\text { stock price changes, } \\
\text { and a negative } \\
\text { relation between } \\
\text { dividend payout } \\
\text { ratio and stock } \\
\text { price changes. }\end{array}$ \\
\hline $\begin{array}{l}\text { Camilleri } \\
\text { et al. } \\
(2019)\end{array}$ & $\begin{array}{l}\text { The effect of } \\
\text { dividend } \\
\text { policy on } \\
\text { share price } \\
\text { volatility: an } \\
\text { analysis of } \\
\text { Mediterranean } \\
\text { banks' stocks }\end{array}$ & $\begin{array}{l}\text { To investigate } \\
\text { the } \\
\text { relationship } \\
\text { between the } \\
\text { share price } \\
\text { volatility of } \\
\text { Mediterranean } \\
\text { banks and } \\
\text { their dividend } \\
\text { policies. }\end{array}$ & $\begin{array}{l}\text { Descriptive } \\
\text { and inferential } \\
\text { statistics }\end{array}$ & $\begin{array}{l}\text { Stock price } \\
\text { volatility, } \\
\text { Dividend yield } \\
\text { and dividend } \\
\text { payout }\end{array}$ & $\begin{array}{l}\text { Dividend yield is } \\
\text { positively related to } \\
\text { stock price } \\
\text { volatility. }\end{array}$ \\
\hline $\begin{array}{l}\text { Ahmad et } \\
\text { al. (2018) }\end{array}$ & $\begin{array}{l}\text { The Effect of } \\
\text { Dividend } \\
\text { Policy on } \\
\text { Stock Price } \\
\text { Volatility: } \\
\text { Empirical } \\
\text { Evidence from } \\
\text { Amman Stock } \\
\text { Exchange }\end{array}$ & $\begin{array}{l}\text { To examine } \\
\text { the effect of } \\
\text { dividend } \\
\text { policy on the } \\
\text { stock price } \\
\text { volatility of } \\
\text { firms listed in } \\
\text { the Amman } \\
\text { Stock } \\
\text { Exchange. }\end{array}$ & $\begin{array}{l}\text { Descriptive } \\
\text { statistics, } \\
\text { Pearson } \\
\text { correlation } \\
\text { and panel } \\
\text { GMM } \\
\text { estimation }\end{array}$ & $\begin{array}{l}\text { Stock price } \\
\text { volatility, } \\
\text { Dividend yield } \\
\text { and dividend } \\
\text { pay-out ratio. }\end{array}$ & $\begin{array}{l}\text { The findings show } \\
\text { that both dividend } \\
\text { yield and dividend } \\
\text { payout have } \\
\text { negative significant } \\
\text { relationship with } \\
\text { stock price } \\
\text { volatility. }\end{array}$ \\
\hline
\end{tabular}

Following the discussion and analysis, it has been found that in most of the cases, dividend policy i.e. dividend yield and dividend payout ratio have significant negative relationship with the stock price volatility. Higher the dividend payout and dividend yield, the lower the stock price volatility. The findings relate to the signaling theory of dividend where the increments of dividend payout convey good signals to the markets related to company's future earnings, which further interprets into upward movements of the share price and the other way around. On the other hand, one of the study's finding also suggest that the dividend policy does not influence the stock prices. The distribution of dividends has no effect on the value of a firm or its share prices, which establishes a significant linkage with the dividend irrelevance theory, which is overlooked in this study because it deviates from majority consensus.

Based on the discussion, Ali and Chowdhury (2010) found that there is no strong evidence that stock price reacts significantly on the announcement of dividend. The findings by Okafor et al. (2011), Hussainey et al. (2011), Hashemijoo et al. (2012), Hunjra et al. (2014), Zainudin et al. (2018) and Ahmad et al. (2018) suggest that there is significant negative relationship of dividend policy with the stock price volatility. While, the study by Camilleri et al. (2019) demonstrate a positive relation of dividend yield with stock price.

The study by Ali and Chowdhury (2010) have well developed a detailed theoretical background on dividend irrelevance theory, signaling theory, free cash flow hypothesis, agency cost theory and bird-inthe-hand theory. The study does not relate the findings back to a wide array of other research studies that were established in its literature, which is a weakness is the study analyzed.Okafor and Mgbame (2011) 
tried to explain their research with an attempt exploring how business dividend policies affect stock prices, including the clientele effect, the information or signaling effect, the bird-in-hand hypothesis, and the rate of return effect. Contradictory to the finding by the authors, it is not deniable that the stock's price often increases after the declaration of a stock dividend. A stock dividend dilutes the book value per common share and lowers the stock price since it increases the number of shares outstanding while the company's worth remains stable.Hussainey et al. (2011) deliberated some theories and determinants of dividend policy, as well as theories of risk and dividends, nevertheless, they did not relate their findings to the dividend relevance theory, which entails a weakness in their part. Hashemijoo et al. (2012) discusses other control variables that impact the stock prices like size of the company. Because micro enterprises often have less diversity in their operations, size is likely to have an influence on price volatility. Hunjra et al. (2014) state that stock prices are uncontrollable, which most of the contemporary firms can relate to. Company's management have little influence on stock prices since many investors assume that swings in stock prices are caused by external variables such as a country's political status.Zainudin et al. (2018) found that earnings volatility was a dominant determinant of price volatility during the crisis. From the discussion, it can be implied that investors are more apprehensive with a firm's earnings stream than with dividend payments during the crisis because earnings play a larger role in explaining stock prices. It has been found that Camilleri et al. (2019) have not theorized their study. When examining the dividend policy, it is essential to establish theoretical background because the results are always consistent with the theories. The findings by Ahmad et al. (2018) are found to be relating to the duration effect theory. It indicates that since high dividend yields may be seen as near cash, reducing uncertainty in businesses' cash flows and resulting in lower discount rate volatility can lead to stronger price stability.

In a nutshell, majority of the studies demonstrate that higher the dividend payout and dividend yield, lower the stock price volatility. The dividend payments earned by the shareholders of the company indicate continuous cash flows obtained from their investment in the stock, which is the primary explanation for the lower volatility with a higher dividend. Second, firms are aware that stocks that lower dividend payments receive a negative reaction from the stock market. As a result, if a company starts paying a regular dividend, it would usually do all it can to continue the trend of paying dividend. This provides investors with a high level of assurance that dividend payments would continue perpetually at the same or a higher level. Under this circumstance, higher dividend-paying stocks are thought to be less volatile. Aside from the dividend policy, additional factors have been discovered to influence the stock price of companies. Because small businesses typically have less diversification in their activities, it's probable that size has an impact on price volatility. Furthermore, it's probable that small businesses have less information about their stock market available to investors leading to price volatility.

\section{Conclusion}

The association between dividend policy and stock price fluctuations is a major topic in finance research because such insights may allow management and stock market traders make decisions. The relationship between dividend policy and stock price volatility is still unresolved, with various academicians debating whether dividend policy has any impact on stock price volatility. Because dividend policy has an influence on shareholder wealth, it is a difficult decision to make. The profits of the company must either be dispersed as a dividend or reinvested in new prospects. This available option raises concerns about 
the amount of profit that will be paid to shareholders against the proportion that will be returned to the business. The purpose of this study was to look at the impact of dividend policy on stock price volatility using information from previous studies. The study analyzed the relationship between the dividend policy and stock price volatility taking 8 selected journal articles for the review following a systematic literature review. The PRISMA flowchart is used to show the whole method of studies inclusion and exclusion.

Through the systematic literature review of the selected articles, it can be observed that most of the articles besides one article, all present a significant impact of dividend policy on the stock prices. The findings of the study indicate that, despite a debating views, majority of the analyzed articles have shown a negative relationship of dividend yield and dividend payout ratio with share price volatility. According to the proposed model of the study, analyzing the majority of cases, the independent variables i.e. dividend payout ratio and dividend yield have a negative relationship with the stock price volatility. The stock prices tend to become less volatile and tend to fluctuate lesser in the market when the company decides paying dividend to its shareholders on a regular basis. Likewise, higher the dividend payout and dividend yield, the lower the stock price volatility.

\section{Implication}

Based on the findings of this study, it can be implied that by changing the dividend policy, company officials may be able to reduce the volatility of their stock prices. Indeed, they may be able to use dividend policy to control share price volatility. They might be able to lessen share price volatility by raising dividend payouts and dividend yield. When a corporation begins paying a regular dividend, it generally does everything in its ability to maintain the dividend-paying pattern. This gives investors a high level of confidence that dividend payments will continue in perpetuity at the same or greater level.Since the study is limited to 4 databases, further studies could include some more articles from top-rated databases that signify dividend policy in diverse sectors to derive even more accurate results.

\section{Reference}

Ahmad, M. A., Alrjoub, A. M. S., \&Alrabba, H. M. (2018). The effect of dividend policy on stock price volatility: Empirical evidence from Amman stock exchange. Academy of Accounting and Financial Studies Journal, 22(2), 1-8.

Ali, M. B., \& Chowdhury, T. A. (2010). Effect of dividend on stock price in emerging stock market: A study on the listed private commercial banks in DSE. International journal of Economics and Finance, 2(4), 52-64. https://doi.org/10.5539/ijef.v2n4p52

Alzomaia, T. S., \& Al-Khadhiri, A. (2013). Determination of dividend policy: The evidence from Saudi Arabia. International Journal of Business and Social Science, 4(1), 181-192.

Camilleri, S. J., Grima, L., \&Grima, S. (2019). The effect of dividend policy on share price volatility: an analysis of Mediterranean banks' stocks. Managerial Finance, 45(2), 348-364. https://doi. org/10.1108/mf-11-2017-0451 
Fairchild, R., Guney, Y., \&Thanatawee, Y. (2014). Corporate dividend policy in Thailand: Theory and evidence. International Review of Financial Analysis, 31, 129-151. https://doi.org/10.1016/j. irfa.2013.10.006

Farrukh, K., Irshad, S., Khakwani, M. S., Ishaque, S., \& Ansari, N. Y. (2017). Impact of dividend policy on shareholders wealth and firm performance in Pakistan. Cogent Business \& Management, 4(1), 1-11. https://doi.org/10.1080/23311975.2017.1408208

Fitri, R. R., Hosen, M. N., \&Muhari, S. (2016). Analysis of factors that impact dividend payout ratio on listed companies at Jakarta Islamic Index. International Journal of Academic Research in Accounting, Finance and Management Sciences, 6(2),87-97. https://doi.org/10.6007/ijarafms/v6$\underline{\mathrm{i} 2 / 2074}$

Gordon, M. J. (1962). The Savings, Investment and Valuation of the Corporation. Review of Economics and Statistics,4(1), 37-51. https://doi.org/10.2307/1926621

Hamid, K., Usman Khurram, M., \& Ghaffar, W. (2017). Juxtaposition of micro and macro dynamics of dividend policy on stock price volatility in financial sector of Pakistan:(Comparative analysis through common, fixed, random and GMM effect). Journal of Accounting, Finance and Auditing Studies, 3(1), 64-79.

Hashemijoo, M., Mahdavi Ardekani, A., \&Younesi, N. (2012). The impact of dividend policy on share price volatility in the Malaysian stock market. Journal of business studies quarterly, 4(1), 111 129.

Huang, C. S., You, C. F., \& Lin, S. H. (2009). Cash dividends, stock dividends and subsequent earnings growth. Pacific-Basin Finance Journal, 17(5), 594-610. https://doi.org/10.1016/j. pacfin.2009.03.002

Hunjra, A. I., Ijaz, M., Chani, D., Irfan, M., \& Mustafa, U. (2014). Impact of dividend policy, earning per share, return on equity, profit after tax on stock prices. International Journal of Economics and Empirical Research, 2(3), 109-115.

Husain, T., \&Sunardi, N. (2020). Firm's Value Prediction Based on Profitability Ratios and Dividend Policy. Finance \& Economics Review, 2(2), 13-26. https://doi.org/10.38157/finance-economicsreview.v2i2.102

Hussainey, K., Mgbame, C. O., \&Chijoke-Mgbame, A. M. (2011). Dividend policy and share price volatility: UK evidence. The Journal of Risk Finance, 12(1), 57-68. https://doi. org/10.1108/15265941111100076

Miller, M. H., \& Modigliani, F. (1961). Dividend policy, growth, and the valuation of shares. The Journal of Business,34(4), 411-433. https://doi.org/10.1086/294442 
Okafor, C. A., \&Chijoke-Mgbame, A. M. (2011). Dividend policy and share price volatility in Nigeria. Journal of Research in National Development, 9(1), 202-210.

Patra, T., Poshakwale, S., \& Ow-Yong, K. (2012). Determinants of corporate dividend policy in Greece. Applied Financial Economics, 22(13), 1079-1087. https://doi.org/10.1080/09603107.2011 .639734

Priya, P. V., \&Mohanasundari, M. (2016). Dividend policy and its impact on firm value: A review of theories and empirical evidence. Journal of Management Sciences and Technology, 3(3), 59-69.

Shah, S. A., \& Noreen, U. (2016). Stock price volatility and role of dividend policy: Empirical evidence from Pakistan. International Journal of Economics and Financial Issues, 6(2).

Zainudin, R., Mahdzan, N. S., \& Yet, C. H. (2018). Dividend policy and stock price volatility of industrial products firms in Malaysia. International Journal of Emerging Markets, 13(1), 203217. https://doi.org/10.1108/ijoem-09-2016-0250 